\title{
Molecular characterization of extended spectrum cephalosporin resistant Escherichia coli isolated from dogs
}

\author{
I.M. Ahmed ${ }^{1}$, S.Y.A. Al-dabbagh ${ }^{1} \odot$ and Dh. M.T. Jwher ${ }^{2} \odot$ \\ ${ }^{1}$ Department of Microbiology, ${ }^{2}$ Department of Veterinary Public Health, College of Veterinary Medicine, University of \\ Mosul, Mosul, Iraq
}

\begin{tabular}{l} 
Article information \\
\hline Article history: \\
Received May 02, 2020 \\
Accepted June 07, 2020 \\
Available online June 23, 2021 \\
\hline Keywords: \\
ESCR E. coli \\
PCR \\
CTX-M gene \\
Shepherd dogs \\
\\
\hline Correspondence: \\
I.M. Ahmed \\
ihsanahmad1 @ yahoo.com
\end{tabular}

\begin{abstract}
Shepherd dogs have been implemented in the transmission and distribution of many threatening pathogens. The presence of extended-spectrum-cephalosporin resistant Escherichia coli (ESCR E. coli) in dog feces can constitute a significance risk to human health due to transmission of antibiotics resistance from dogs to humans, other animals and the surrounding environment. Therefore, in this study, phenotypic and molecular characterization of fecal ESCR E. coli were investigated in shepherd dogs accompanied sheepherders in urban areas. Sixty-seven fresh fecal samples were collected from shepherd dogs from different regions of Mosul city. Bacteriological examination of ESCR E. coli was done using MacConkey agar with cefotaxime followed by subsequent PCR confirmation of the CTX-M gene using specific primers and molecular characterization using specific primers directed to CTX-M-1, 2 and 9 groups. The results of bacterial examination showed successful confirmation of ESCR E. coli which has been isolated from fecal samples of shepherd dogs $58.2 \%$ (39/67). In addition, detection of CTX-M gene was confirmed in $53.7 \%$ (36/67) of $E$. coli isolates. Furthermore, molecular characterization of CTX-M gene revealed the presence of only one genotype belongs to CTX-M-1. However, both of CTXM-2 and CTX-M-9 genotypes were not detected in this study. This study concluded that shepherd dogs have an essential role in carrying and spreading of ESCR E. coli especially in urban regions.
\end{abstract}

DOI: $10.33899 /$ ijvs.2020.127032.1441, @2021, College of Veterinary Medicine, University of Mosul.

This is an open access article under the CC BY 4.0 license (http://creativecommons.org/licenses/by/4.0/).

\section{Introduction}

Dogs play an important role in human daily practices as they mainly kept as companion pets $(1,2)$. In addition, they are used in many diverse activities such as animal grazing, livestock guarding, and thus it's in close contact with humans $(3,4)$. One of the most common farming practices of sheep and goats in urban areas of Mosul city is keeping stray dogs as shepherd dogs along with these flocks to provide protection and control of the animal movement. Nevertheless, most of these dogs mainly did not receive any treatments or vaccinations which render them as potential risk for transmission of many pathogens and diseases (3-6). Recent studies approved that many bacterial species have developed antimicrobial resistance especially in dogs $(1,7,8)$ and this resistance might be transmitted to human (9). Spreading of beta-lactamase-producing Enterobacteriaceae is considered as one of the most important bacterial pathogens associated with high costs of health care and also unresponsiveness to treatment $(7,10,11)$. Nevertheless, increased spreading of extended-spectrum $\beta$-lactamase (ESBL) bacteria was potentially related to the common pathogen for many infections. In addition, its treatment has become more difficult because of its resistance to antibiotics (12-14). Yet, the spreading of extended-spectrum cephalosporin resistance E. coli (ESCR E. coli) infections has complicated the scene and become a major challenge due to substantial genetic diversity, possession of virulence 
factors, large and wide hosts range, multifaceted potential and various pathogenic forms and the possibility of infection and spreading among multiple hosts within the environment (12-16). A plasmid-mediated CTX-M $\beta$-lactamase has become a dominant type of ESBLs, especially ESCR E. coli, rather other classical $\beta$-lactamases such as SHV-and TEMtypes (17-19). CTX-M type has been increasingly recorded in human and animal worldwide with most prevalent groups CTX-M-1, CTX-M-2 and CTX-M-9 (4,12,17-19). Giving the fact, there is no information about spreading of ESCR $E$. coli in the shepherd dogs in Mosul city, in addition to lack of local studies which indicate the possibility of dogs as a transporter of ESCR E. coli. Therefore, this study aimed to detect and molecular characterize ESCR E. coli in shepherd dogs.

\section{Materials and methods}

\section{Sampling}

A Total of 67 fresh fecal samples of apparently health shepherd dogs were collected in sterile containers from both sexes (male and female), ranging from 6 months to 3 years in age from different urban regions of Mosul city for the period from December 2019 to February 2020. The samples were transported immediately under cooling conditions to the Microbiology Laboratory, College of Veterinary Medicine, University of Mosul, for further microbiological examination.

\section{Isolation and identification of ESCR $E$. coli}

A loopful of the collected fecal sample was cultured on special MacConkey agar with cefotaxime (Foxime $500 \mathrm{mg}$, Tabuk, KSA) at $1 \mu \mathrm{g} / \mathrm{ml}$ final concentration according to Umeda et al. (15). After that, all the inoculated plates were put in the incubator at $37^{\circ} \mathrm{C}$ for $24 \mathrm{~h}$. This medium inhibits all the bacteria that are sensitive to cefotaxime and allows only resistant ones to grow. All suspected fermented ESCR E. coli colonies were again subculture on MacConkey agar with cefotaxime for purification and subsequent identification using standard bacteriological methods (20).

\section{Molecular characterization \\ Extraction of DNA}

Only ESCR E. coli positive colonies were subjected to DNA extraction using Bacteria DNA Preparation Cat No. PP-206S (Jena Bioscience, Germany). According to the manufacturer instructions, briefly, few fresh colonies on Brain Heart Infusion agar (Lab M, UK) were selected and suspended in an eppendorf microcentrifuge for cell Lysis. Then, followed by a step of precipitation of proteins. After that the supernatant was separated in a new sterile $1.5 \mathrm{ml}$ eppendorf tube with $300 \mu 1$ Isopropanol $99 \%$. This step was necessary for DNA precipitation. The tube was centrifuged and the supernatant was discarded followed by draining of the tube. The small DNA pellet was washed by adding washing buffer, inverted several times then centrifuged. The supernatant was eliminated and the tube was dried in air at room temperature. Hydration of DNA was done by adding $100 \mu$ of Hydration Solution, followed by incubation at 65 ${ }^{\circ} \mathrm{C}$ for $1 \mathrm{~h}$, and then the DNA was kept at $-20{ }^{\circ} \mathrm{C}$ for subsequent testing.

\section{Polymerase chain reaction (PCR) assay procedure}

All the primers used in this study were detailed in (Table $1)$. The molecular confirmation of E. coli was performed using species specific primers (E. coli: ECO223-F and ECO 455-R). While confirmation of the CTX-M gene was done by CTX-M-Uni-F and CTX-M-Uni-R. Subsequent characterization of CTX-M groups was done using 3 set of primers targeting G1, G2 and G9 groups of the CTX-M gene. Standard PCR reaction mixture was prepared for all protocols. Briefly, $25 \mu$ l containing $12.5 \mu$ l HS Prime Taq Premix (2X) (GeNet Bio, Korea), $1 \mu \mathrm{M}$ of each primer 10 mmol (IDT, USA), $2.5 \mu \mathrm{l}$ of DNA template final concentration $(2 \mathrm{ng} / \mu \mathrm{l})$ and $8 \mu \mathrm{l}$ of PCR grade water. The PCR was done using thermal cycler (BioRad, T100, BioRad, USA). The cycling conditions include 1 cycle of initial denaturation at $94{ }^{\circ} \mathrm{C}$ for $10 \mathrm{~min}, 35$ cycles consisting of (initial denaturation at $94^{\circ} \mathrm{C}$ for $30 \mathrm{sec}$, annealing at $\left(55^{\circ} \mathrm{C}\right.$ for E. coli, $54{ }^{\circ} \mathrm{C}$ for CTX-M-Uni and 52 for CTX-M G1, $\mathrm{G} 2, \mathrm{G} 3$ ) for $30 \mathrm{sec}$, and extension at $72{ }^{\circ} \mathrm{C}$ for $45 \mathrm{sec}$ ). Finally, one cycle of final extension at $72{ }^{\circ} \mathrm{C}$ for $5 \mathrm{~min}$. The reaction was set for cooling at $4{ }^{\circ} \mathrm{C}$. Agarose gel electrophoresis was used to separate the PCR products using $1.2 \%$ agarose gel (Promega, USA) containing Prime safe Dye (GeNet Bio, Korea). The wells of agarose gel were loaded by $5 \mu 1$ of each PCR product. The electrophoresis condition was set at $75 \mathrm{~V}, 300 \mathrm{~mA}$ for $50 \mathrm{~min}$ using Wide Mini-Sub Cell GT gel electrophoresis systems and basic power supply (Bio-Rad, USA) containing $1 \mathrm{X}$ TBE buffer (Bio-Rad, USA). A volume of $4 \mu \mathrm{l}$ of DNA ladder, $100 \mathrm{bp}$ (GeNet Bio, Korea) was used as molecular weight standard. Following electrophoresis, the gel was viewed using Gel doc Ez system (Bio-Rad-USA) to detect the specific bands.

\section{Results}

The bacterial isolation and identification showed successful recovery of ESCR E. coli from fecal samples 58.2\% (39/67) using MacConkey agar with cefotaxime (Figure 1). However, only 53.7\% (36/67) isolates were confirmed E. coli by PCR producing expected product size of 232 bp (Figure 2). Additionally, all the 36 positive samples of $E$. coli showed positive for the CTX-M universal gene with expected band size of 550 bp (Figure 3). Furthermore, Molecular characterization of the CTX-M gene using primers directed to CTX-M-1, 2 and 9 showed that all the isolates were belong to CTX-M-1 with product size of 415 bp. However, neither CTX-M-2 nor CTX-M-9 was confirmed in the examined samples (Figure 4). 
Table1: Primers used for PCR

\begin{tabular}{|c|c|c|c|c|c|}
\hline No. & Primer Name & Sequence $5^{\prime}-3^{\prime}$ & $\mathrm{Tm}{ }^{\circ} \mathrm{C}$ & Product size $(\mathrm{bp})$ & Ref. \\
\hline 1 & ECO223-F & ATCAACCGAGATTCCCCCAGT & \multirow{2}{*}{55} & \multirow{2}{*}{232} & \multirow{2}{*}{ (21) } \\
\hline 2 & $\mathrm{ECO} 455-\mathrm{R}$ & TCACTATCGGTCAGTCAGGAG & & & \\
\hline 3 & CTX-M-Uni-F & CGCTTTGCGATGTGCAG & \multirow{2}{*}{54} & \multirow{2}{*}{550} & \multirow{2}{*}{$(22)$} \\
\hline 4 & CTX-M-Uni-R & ACCGCGATATCGTTGGT & & & \\
\hline 5 & CTX-M G1-F & AAAAATCACTGCGCCAGTTC & \multirow{2}{*}{52} & \multirow{2}{*}{415} & \multirow{2}{*}{ (23) } \\
\hline 6 & CTX-M G1-R & AGCTTATTCATCGCCACGTT & & & \\
\hline 7 & CTX-M G2-F & CGACGCTACCCCTGCTATT & \multirow{2}{*}{52} & \multirow{2}{*}{552} & \multirow{2}{*}{$(23)$} \\
\hline 8 & CTX-M G2-R & CCAGCGTCAGATTTTTCAGG & & & \\
\hline 9 & CTX-M G9-F & CAAAGAGAGTGCAACGGATG & \multirow{2}{*}{52} & \multirow{2}{*}{205} & \multirow{2}{*}{ (23) } \\
\hline 10 & CTX-M G9-R & ATTGGAAAGCGTTCATCACC & & & \\
\hline
\end{tabular}
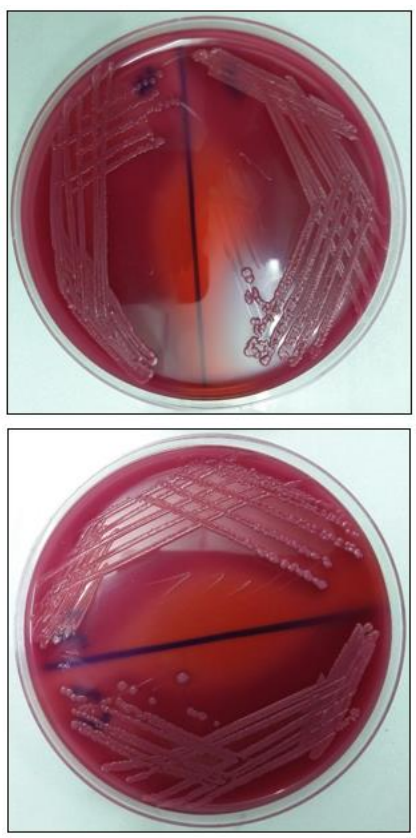

Figure 1: Isolation of ESCR E. coli using specific MacConkey agar with cefotaxime showing characteristic small lactose fermenting colonies.

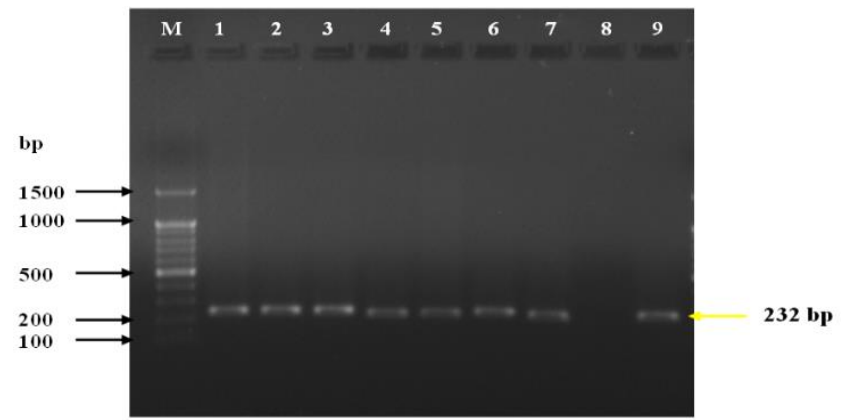

Figure 2: PCR products of E. coli. Lane M, DNA molecular standard; lane 1-7 positive tested samples giving 232 bp product size; lane 8 , negative control and lane 9 control positive.

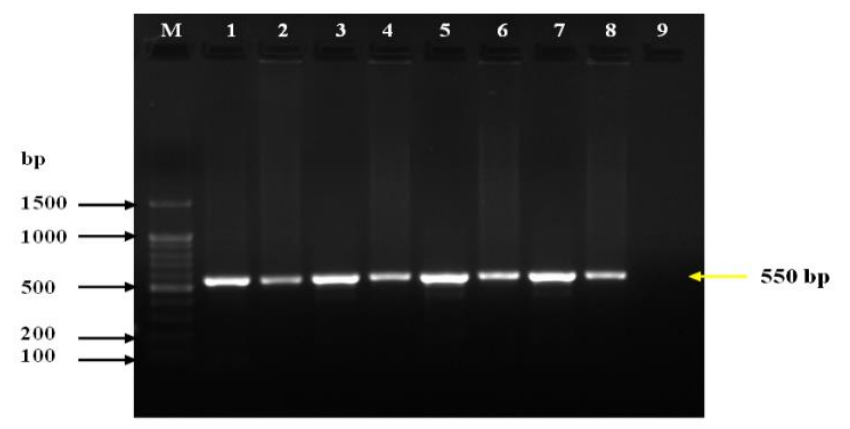

Figure 3: PCR products of CTX-M universal gene. Lane M, DNA molecular standard; lane 1-8 positive tested samples giving 550 bp product size; lane 9 , control negative.

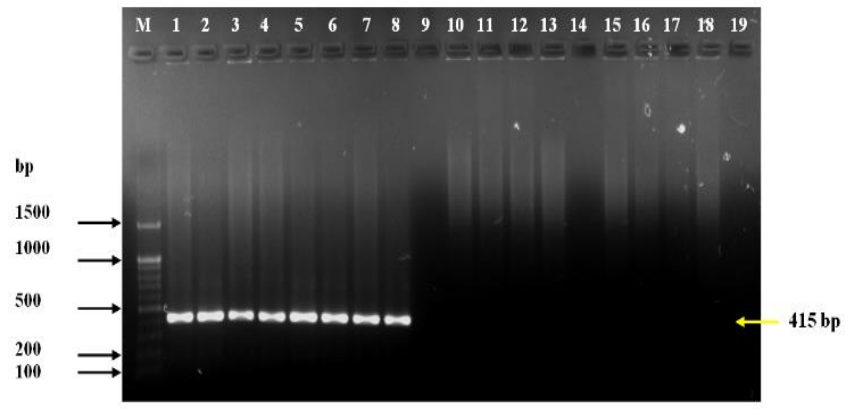

Figure 4: PCR products of CTX-M gene characterization using specific primers set. Lane M, DNA molecular standard; lane 1-8 are positive tested samples of CTX-M G1 giving 415 bp product size; lane 10-13 are negative tested samples for CTX-M G2, and lane 15-18 are samples negative tested samples for CTX-M G9.

\section{Discussion}

Globally, antibiotic resistance has become a serious threat and widely distributed in humans, animals and the environment (18,24-27). Nevertheless, dog feces are well known as a potential source of many zoonotic diseases and also spreading of different types of bacteria which are 
resistant to antibiotics $(2,5,28,29)$. In this study we investigated a type of stray dogs that are used commonly as shepherd dogs in our community and they are almost with contact with the animals especially sheep and goats in addition to the grazers themselves. Our results showed that $53.7 \%(36 / 67)$ of the shepherd dogs were confirmed positive for ESCR E. coli and possess CTX-M gene using standard bacteriological culture and PCR as a molecular confirmation method. This result was in consistent with the previous findings obtained by Hong et al. (9), they reported that 49.2\% (155/315) of dogs were positive for ESCR E. coli. Another recent study by Abbas et al. (30) revealed that $69.5 \%(73 / 105)$ of screened fecal samples obtained from dogs, cats and their owners in addition to veterinary professionals were found positive for ESBLR E. coli. However, isolates among dogs were the highest number $81.8 \%$ (18/22). Other study by Zhang et al. (31) targeted healthy dogs in different parks in Ontario, Canada revealed that fecal carriage of ESCR Enterobacteriaceae was 26.5\% of with majority belongs to ESCR E. coli, while ESCR Klebsiella pneumoniae and Proteus mirabilis recorded less. Also Umeda et al. (15) found that 22/151 (14.6\%) of dogs were Cephalosporin-resistant Enterobacteriaceae with majority identifies as ESCR E. coli. This variation in the results may reflect the strict use of antibiotics in different countries. It is clear that the presence of ESCR Enterobacteriaceae especially ESCR E. coli in fecal samples of dogs is considered as a potential risk factor for spreading of antimicrobial resistance by these animals to other animal species, close contact humans and the environment (18,3234). This mainly occurred by contamination of the ground, pasture and water by feces of roaming shepherd dogs with ESCR type of bacteria. Among the ESBL genotypes of Enterobacteriaceae, the CTX-M type ESBL genes were frequently studied in both human and veterinary fields with almost dominant of ESCR E. coli $(9,24,25,35)$. In this study the CTX-M-1 was the only detected genotype, while CTXM-2 and CTX-M-9 were not confirmed. This was in agreement with Damborg et al. (29), they reported isolation of ESBL with predominant CTX-M-1 genotype confirmed by multilocus sequence typing (MLST). While Haenni et al. (36) found that most of ESBL E. coli isolates belonged to CTX-M-1 and CTX-M-2. Also, Abbas et al. (30) reported high rates of the CTX-M genes of isolated ESBL E. coli with dominating CTX-M-1 genotype in all positive isolates. However, other groups of CTX-M have been studied by others such as CTX-M-2 (33,35), CTX-M-9 (13,33), CTXM-14 $(8,37)$, CTX-M-15 $(15,29,38)$ or even miscellaneous CTX-M groups like CTX-M-24, CTX-M-27, CTX-M-55 (8, 15). In addition, other genes also have been reported especially, those within ESBL such as SHV, CMY groups (37-39), TEM (39), or other types rather than ESBL such as AmpC $\beta$-lactamase (pAmpC) $(28,33,37)$ and carbapenemase $(25,40)$. Finally, the dramatic spreading of antibiotic resistance has a great impact on human in terms of one health concept though increasing the probability of fecal contamination by such kind of shepherd dogs, various animal species and also the environment worldwide. More studies have to be conducted to understand the relation between resistant bacteria isolates from different sources. Such information will surely help to mitigate and control the spreading of antibiotic resistance to a more dangerous level especially development of different pathogens, including multidrug-resistant once.

\section{Conclusion}

ESCR E. coli was successfully detected in shepherd dogs with common CTX-M G1 type. Shepherd dogs are considered as one of the most neglected sources of spreading and transmission of ESCR E. coli.

\section{Acknowledgments}

The authors would like to thanks College of Veterinary Medicine, University of Mosul, Mosul, Iraq.

\section{Conflict of interest}

The author declare that he has no conflict of interest.

\section{References}

1. Liakopoulos A, Betts J, La Ragione R, van Essen-Zandbergen A, Ceccarelli D, Petinaki E, Koutinas CK, Mevius DJ. Occurrence and characterization of extended-spectrum cephalosporin-resistant Enterobacteriaceae in healthy household dogs in Greece. J Med Microbiol. 2018;67:931-5. DOI: 10.1099/jmm.0.000768

2. Leonard EK, Pearl DL, Finley RL, Janecko N, Reid-Smith RJ, Peregrine AS, Weese JS. Comparison of antimicrobial resistance patterns of Salmonella spp. and Escherichia coli recovered from pet dogs from volunteer households in Ontario (2005-06). J Antimicrob Chemother. 2012;67:174-81. DOI: 10.1093/jac/dkr430

3. Guilloux AG, Panachão LI, Alves AJ, Zetun CB, Cassenote AJ, Dias RA. Stray dogs in urban fragments: relation between population's perception of their presence and socio-demographic factors. Pesqui. Vet. Bras. 2018;38:89-93. DOI: 10.1590/1678-5150-pvb-4293

4. Tamang MD, Nam H-M, Jang G-C, Kim S-R, Chae MH, Jung S-C, Byun J-W, Park YH, Lim S-K. Molecular characterization of extendedspectrum- $\beta$-lactamase-producing and plasmid-mediated AmpC $\beta$ lactamase-producing Escherichia coli isolated from stray dogs in South Korea. Antimicrob Agents Chemother. 2012;56:2705-12. DOI: 10.1128/AAC.05598-11

5. Jwher D. Prevalence and distribution of canine visceral leishmaniasis antibodies in dogs in Mosul City. Iraqi J Vet Sci. 2012;26:63-7. DOI: 10.33899/ijvs.2012.67443

6. Dalla Villa P, Kahn S, Stuardo L, Iannetti L, Di Nardo A, Serpell J. Free-roaming dog control among OIE-member countries. Prev Vet Med. 2010;97:58-63. DOI: 10.1016/j.prevetmed.2010.07.001

7. Harada K, Shimizu T, Mukai Y, Kuwajima K, Sato T, Kajino A, et al. Phenotypic and molecular characterization of antimicrobial resistance in Enterobacter spp. isolates from companion animals in Japan. PLoS One. 2017;12(3):174-178. DOI: 10.1371 /journal.pone.0174178

8. Harada K, Shimizu T, Mukai Y, Kuwajima K, Sato T, Usui M, Tamura Y, Kimura Y, Miyamoto T, Tsuyuki Y. Phenotypic and molecular characterization of antimicrobial resistance in Klebsiella spp. isolates from companion animals in Japan: clonal dissemination of multidrug- 
resistant extended-spectrum $\quad \beta$-lactamase-producing Klebsiella pneumoniae. Front microbiol. 2016;7:1021. DOI: 10.3389/fmicb.2016.01021

9. Hong JS, Song W, Park H-M, Oh J-Y, Chae J-C, Shin S, Jeong SH. Clonal spread of extended-spectrum cephalosporin-resistant Enterobacteriaceae between companion animals and humans in South Korea. . Front Microbiol. 2019;10:1371. DOI: 10.3389/fmicb.2019.01371

10. Paterson DL, Bonomo RA. Extended-Spectrum $\beta$-Lactamases: a Clinical Update. Clin Microbiol Rev. 2005;18:657-686. DOI: 10.1128/CMR.18.4.657-686.2005

11. Palmeira JD, Ferreira HMN. Extended-spectrum beta-lactamase (ESBL)-producing Enterobacteriaceae in cattle production-a threat around the world. Heliyon. 2020;6:e03206. DOI: 10.1016/j.heliyon.2020.e03206

12. Ortega-Paredes D, Haro M, Leoro-Garzón P, Barba P, Loaiza K, Mora F, Fors M, Vinueza-Burgos C, Fernández-Moreira E. Multidrugresistant Escherichia coli isolated from canine faeces in a public park in Quito, Ecuador. J Glob Antimicrob Resist. 2019;18:263-268. DOI: 10.1016/j.jgar.2019.04.002

13. Takagi H, Yamane K, Matsui M, Suzuki S, Ito K. Pathotypes and drug susceptibility of Escherichia coli isolated from companion dogs in Japan. Jpn J Infect Dis. 2020:JJID. 2019.122. DOI: 10.7883/yoken.JJID.2019.122

14. Al-Sharook M, Hassan A. Isolation and identification of extendedspectrum beta-lactamase (ESBL)-producing Escherichia coli from broiler in Erbil, Iraq. Iraqi J Vet Sci. 2017;31:31-8. DOI: 10.33899/ijvs.2017.126717

15. Umeda K, Hase A, Matsuo M, Horimoto T, Ogasawara J. Prevalence and genetic characterization of cephalosporin-resistant Enterobacteriaceae among dogs and cats in an animal shelter. J Med Microbiol. 2019;68:339-45. DOI: 10.1099/jmm.0.000933

16. Naji H, Saleh W, Hanoon M, Imad I, Salim Y. Serotyping, virulence gene expression and phenotypic characterization of E. coli O157: $\mathrm{H} 7$ in colibacillosis affecting buffalo calves in Basra governorate. Iraqi J Vet Sci. 2019;33:447-51. DOI: 10.33899/ijvs.2019.163198

17. Liu H, Zhou H, Li Q, Peng Q, Zhao Q, Wang J, Liu X. Molecular characteristics of extended-spectrum $\beta$-lactamase-producing Escherichia coli isolated from the rivers and lakes in Northwest China. BMC microbiol. 2018;18:125. DOI: 10.1186/s12866-018-1270-0

18. Lee S, Mir RA, Park SH, Kim D, Kim H-Y, Boughton RK, Morris Jr JG, Jeong KC. Prevalence of extended-spectrum $\beta$-lactamases in the local farm environment and livestock: challenges to mitigate antimicrobial resistance. Crit Rev Microbiol. 2020:1-14. DOI: 10.1080/1040841x.2020.1715339

19. Ahmed, I. M. (2021). Detection of CTX-M gene in extended spectrum $\beta$-lactamases producing Enterobacteriaceae isolated from bovine milk. Iraqi J Vet Sci. 2021;35(2), 397-402. DOI: 10.33899/ijvs.2020.126909.1412

20. Brooks G, Carroll K, Butel J, Morse S, Mietzner T. Jawetz, Melnick, Adelberg Medical Microbiology: Placebo doo; 2015. ISBN-13: 978980 -07-128735- 7.

21. Riffon R, Sayasith K, Khalil H, Dubreuil P, Drolet M, Lagacé J. Development of a rapid and sensitive test for identification of major pathogens in bovine mastitis by PCR. J clinical microbiol. 2001;39:2584-2589. DOI: 10.1128/JCM.39.7.2584-2589.2001

22. Ali T, Zhang L, Shahid M, Zhang S, Liu G, Gao J, Han B. ESBLproducing Escherichia coli from cows suffering mastitis in China contain clinical class 1 integrons with CTX-M linked to ISCR1. Front Microbiol. 2016;7:1931. DOI: 10.3389/fmicb.2016.01931

23. Woodford N, Fagan EJ, Ellington MJ. Multiplex PCR for rapid detection of genes encoding CTX-M extended-spectrum $\beta$-lactamases. J Antimicrob chemother. 2006;57:154-155. DOI: 10.1093/jac/dki412

24. Alegría Á, Arias-Temprano M, Fernández-Natal I, Rodríguez-Calleja JM, García-López M-L, Santos JA. Molecular Diversity of ESBLProducing Escherichia coli from Foods of Animal Origin and Human Patients. Int J Environ Res Public Health. 2020;17:1312. DOI: $\underline{10.3390 / i j e r p h 17041312}$
25. Madec J-Y, Haenni M, Nordmann P, Poirel L. Extended-spectrum $\beta$ lactamase/AmpC-and carbapenemase-producing Enterobacteriaceae in animals: a threat for humans? Clin Microbiol Infect J. 2017;23:826-33. DOI: $10.1016 /$ j.cmi.2017.01.013

26. Yousif, S. A. and Jwher, D. M. (2021). Detection of multiple presence of antibiotic residues in slaughtered sheep at Duhok abattoir, Iraq. Iraqi J Vet Sci. 2021;35(1), 49-55. DOI: 10.33899/ijvs.2019.126259.1276

27. Taha, Z. M., Sadiq, S. T., Khalil, W. A., Muhammad-Ali, K. Y., Yosif, H. S. and Shamil, H. N. (2021). Investigation of gcat gene and antibiotic resistance pattern of Aeromonas hydrophila isolated from hemorrhagic septicemia's cases in fish farms. Iraqi J Vet Sci. 2021;35(2), 375-380. DOI: $10.33899 /$ ijvs.2020.126876.1405

28. Aslantas Ö, Yilmaz ES. Prevalence and molecular characterization of extended-spectrum $\beta$-lactamase (ESBL) and plasmidic AmpC $\beta$ lactamase (pAmpC) producing Escherichia coli in dogs. J Vet Med Sci. 2017;79:1024-1030. DOI: $10.1292 /$ jvms.16-0432

29. Damborg P, Morsing MK, Petersen T, Bortolaia V, Guardabassi L. CTX-M-1 and CTX-M-15-producing Escherichia coli in dog faeces from public gardens. Acta Vet Scand. 2015;57:83. DOI: 10.1186/s13028-015-0174-3

30. Abbas G, Khan I, Mohsin M. High rates of CTX-M group-1 extendedspectrum $\beta$-lactamases producing Escherichia coli from pets and their owners in Faisalabad, Pakistan. Infect Drug Resist. 2019;12:571. DOI: 10.2147/IDR.S189884

31. Zhang PL, Shen X, Chalmers G, Reid-Smith RJ, Slavic D, Dick H, Boerlin P. Prevalence and mechanisms of extended-spectrum cephalosporin resistance in clinical and fecal Enterobacteriaceae isolates from dogs in Ontario, Canada. Vet microbiol. 2018;213:82-8. DOI: 10.1016/j.vetmic.2017.11.020

32. Rousham EK, Unicomb L, Islam MA. Human, animal and environmental contributors to antibiotic resistance in low-resource settings: integrating behavioural, epidemiological and One Health approaches. Proceedings of the Royal Society B: Biol Sci. 2018;285:20180332. DOI: 10.1098/rspb.2018.0332

33. Melo LC, Oresco C, Leigue L, Netto HM, Melville PA, Benites NR, Saras E, Haenni M, Lincopan N, Madec J-Y. Prevalence and molecular features of ESBL/pAmpC-producing Enterobacteriaceae in healthy and diseased companion animals in Brazil. Vet Microbiol. 2018;221:59-66. DOI: $10.1016 /$ j.vetmic.2018.05.017

34. Dahms C, Hübner N-O, Kossow A, Mellmann A, Dittmann K, Kramer A. Occurrence of ESBL-producing Escherichia coli in livestock and farm workers in Mecklenburg-Western Pomerania, Germany. PloS One. 2015;10. DOI: 10.1371/journal.pone.0143326

35. Bevan ER, Jones AM, Hawkey PM. Global epidemiology of CTX-M $\beta$-lactamases: temporal and geographical shifts in genotype. J Antimicrob Chemother. 2017;72:2145-55. DOI: 10.1093/jac/dkx146

36. Haenni M, Saras E, Métayer V, Médaille C, Madec J-Y. High prevalence of blaCTX-M-1/IncI1/ST3 and blaCMY-2/IncI1/ST2 plasmids in healthy urban dogs in France. Antimicrob Agents Chemother. 2014;58:5358-5362. DOI:10.1128/AAC.00819-15

37. Baede VO, Wagenaar JA, Broens EM, Duim B, Dohmen W, Nijsse R, Timmerman AJ, Hordijk J. Longitudinal study of extended-spectrum$\beta$-lactamase-and AmpC-producing Enterobacteriaceae in household dogs. Antimicrob Agents Chemother. 2015;59:3117-3124. DOI: 10.1128/AAC.04576-14

38. Rocha-Gracia R, Cortés-Cortés G, Lozano-Zarain P, Bello F, MartínezLaguna Y, Torres C. Faecal Escherichia coli isolates from healthy dogs harbour CTX-M-15 and CMY-2 $\beta$-lactamases. Vet J. 2015;20(3):315319. DOI:10.1016/j.tvjl.2014.12.026

39. Shaheen BW, Nayak R, Foley SL, Kweon O, Deck J, Park M, Rafii F, Boothe DM. Molecular characterization of resistance to extendedspectrum cephalosporins in clinical Escherichia coli isolates from companion animals in the United States. Antimicrob Agents Chemother. 2011;55:5666-75. DOI: 10.1128/AAC.00656-11

40. Pulss S, Stolle I, Stamm I, Leidner U, Heydel C, Semmler T, PrengerBerninghoff E, Ewers C. Multispecies and clonal dissemination of OXA-48 carbapenemase in Enterobacteriaceae from companion animals in Germany, 2009-2016. Front Microbiol. 2018;9:1265. DOI: $10.3389 /$ fmicb.2018.01265 


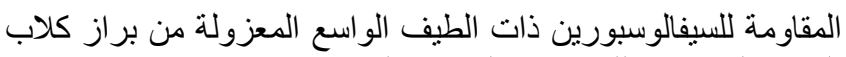

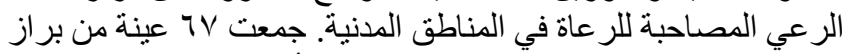

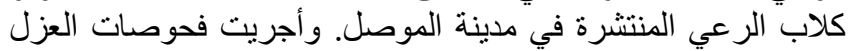

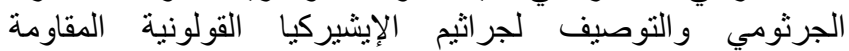

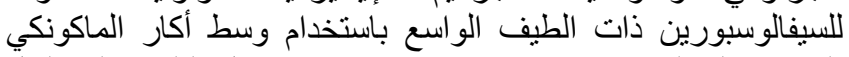

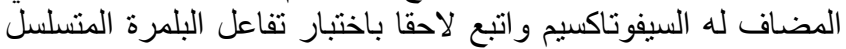

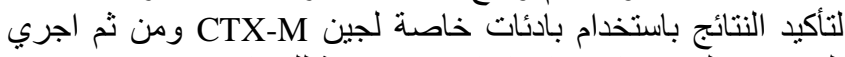

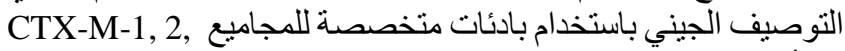

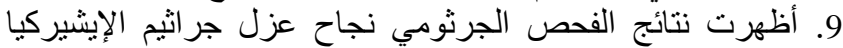

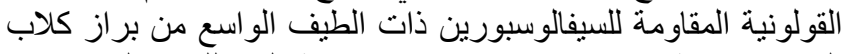

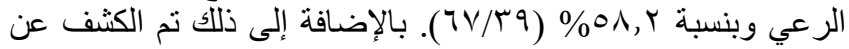

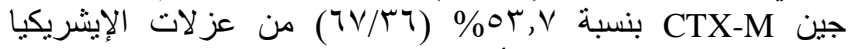

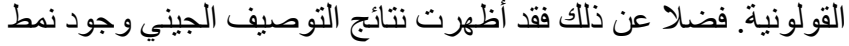

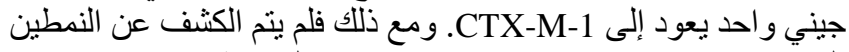

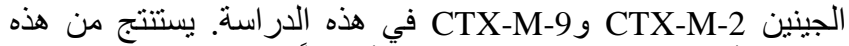

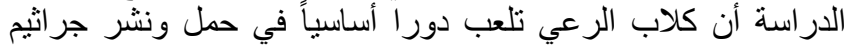

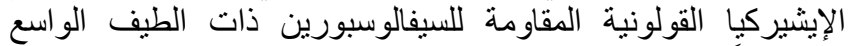
خصوصاً في المناطق المدنية.

\section{التوصيف الجزيئي لجراثيم الإيشيركيا القولونية

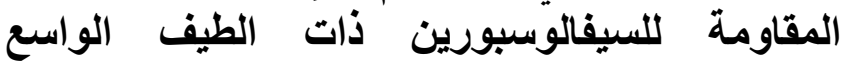 والمعزولة من الكلاب}

إحسان منير احمد'، سمية ياسين عبد الله الاباغ' و ضياء محمد طاهر جوهرن

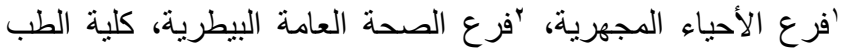

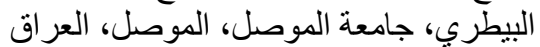

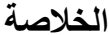

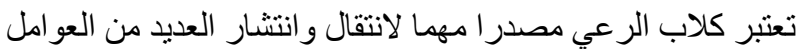

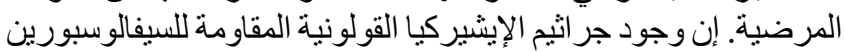

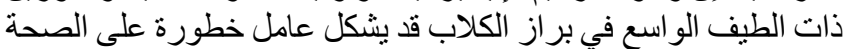

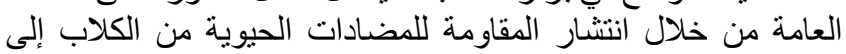

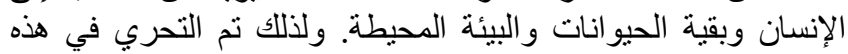
الدراسة عن الصفات المظهرية والجزيئية لجر اثيم الإيشيركيًا القولونية 